\title{
The usage of e-resources among agricultural researchers and extension staff in Tanzania
}

\author{
Wulystan Pius Mtega, Frankwell Dulle, Andrew Watson Malekani, Angella \\ Chailla
}

\begin{abstract}
This article investigates the accessibility and usage of e-resources among agricultural researchers and extension staff in five out of seven agricultural zones in Tanzania. The study identifies sources of e-resources used by these researchers and staff, as well as assessing their information literacy levels and the factors influencing their usage of e-resources. The research used a survey approach based on convenient non-probability sampling.

Findings show that usage of e-resources from popular agricultural databases remains low. Factors limiting access to e-resources include poor institutional ICT infrastructure, limited funds for e-resources and low information literacy levels. Recommendations include improvements to ICT infrastructure and budgets, as well as developing electronic institutional repositories to improve extension staff access to research outputs, creating a sustainable link between agricultural research and farming activities. Information literacy modules in agricultural training institutes could also support effective access to, and use of, e-resources.
\end{abstract}

\section{Introduction and background}

Agriculture is the largest sector of the economy in Tanzania supporting about $70 \%$ of the total population, living in rural areas (United Republic of Tanzania, 2011). Tanzania's history of agricultural research and development can be traced back to 1893 when large scale commercial farming was introduced. According to Carr $e t$

\section{Author}

Wulystan Pius Mtega, Sokoine University of Agriculture, Morogoro, Tanzania.

Email: wmtega@suanet.ac.tz

Frankwell Dulle, Sokoine University of Agriculture, Morogoro, Tanzania and Department of Information Science, University of South Africa.

Andrew Watson Malekani, Sokoine University of Agriculture, Morogoro, Tanzania.

Angella Chailla, Sokoine University of Agriculture, Morogoro, Tanzania. 
al. (1992), cash crop experiments started in 1904 while food crop experiments started in the 1950s. These experiments aimed to improve agricultural yield by producing better seeds. Agricultural experiments follow specific procedures and steps, all requiring knowledge. In order to improve agricultural production, results of research were communicated to large farms.

After independence, Tanzania established the National Agricultural Research System (NARS) with research institutes in each of the seven agricultural ecological zones (Kapange, 2004). NARS is made up of Agricultural Research Institutes which create agricultural information and other outputs needed in order to improve agricultural productivity. Shetto (2008) describes how research outputs are linked to farmers through agricultural extension staff who are positioned in each ward. Appropriate communication channels are needed to improve the link between agricultural research institutes and extension staff. For years, print resources have been used for disseminating newly created knowledge to agricultural extension staff and farmers.

Despite the notable effort in agricultural research in Tanzania, the full contribution of agriculture to the economic growth and poverty reduction has not been realised (Chailla, 2001; United Republic of Tanzania, 2005; United Republic of Tanzania, 2008). Siyao (2012) describes how lack of access to the current, relevant and appropriate agricultural information needed for decision-making has limited the transformation of the agricultural sector and farmers' livelihoods.

Advancements in the Information and Communication Technology (ICT) form an important solution for linking agricultural research institutes and the extension system. ICT facilitates the capture, processing, storing, and communication of information (Heeks, 1999). ICTs differ by level of interactivity. Traditional ICTs are less interactive, such as radio, telephony and TV. Sife, Lwoga and Sanga (2007) identify more interactive ICTs, such as the internet, mobile phones and computers. These allow greater collaboration and can be described as modern ICTs. The importance of ICTs in linking the agricultural research and the extension system arises from the fact that agricultural research institutes are isolated and far away from farms (Coulson and Diyamett, 2012). Shetto (2008) found that most agricultural research institutes have basic ICT tools needed to process and disseminate information emanating from research activities.

ICTs have revolutionized not only the way information is packaged, processed, stored, and disseminated, but also how users seek and access information (Anunobi and Okoye, 2008). Richardson (1996) describes ICTs to facilitate the interactions between researchers, extension workers and farmers. These technologies enhance timely access to information needed for decision making. ICTs are useful to agricultural researchers as they enhance access to information needed for research work. Agricultural extension staff can use the tools to forward practical problems to research institutes and use the same tools to access information from different sources including research institutes. E-resources can also be easily accessed and used, making it possible for agricultural stakeholders to make rational decisions. This study was motivated by inadequate documented evidence about the extent of ICT usage in facilitating information access and sharing among agricultural practitioners in Tanzania. This study therefore 
investigates the use of electronic information resources among agricultural researchers and extension staff in Tanzania.

\section{Objectives of the study and conceptual framework}

\section{$2.1 \quad$ Objectives}

The aim of the study was to assess how agricultural researchers and extension staff accessed and used electronic resources for their day to day activities. Specifically, the study objectives were to:

1. Identify the sources of e-resources agricultural researchers and extension staff;

2. Determine the e-resource access points used by agricultural researchers and extension staff;

3. Assess the information literacy level among agricultural researchers and extension staff;

4. Determine factors influencing the usage of e-resources among agricultural researchers and extension staff in Tanzania.

\subsection{Conceptual framework}

This study was guided by the Quadratic Usage Framework (QUF) in investigating how agricultural researchers and extensions staff used ICTs to access e-resources. QUF can assist in explaining factors that influence the acceptance, intention to use and usage of a technology (Mardis, Hoffman and Marshall, 2008). QUF guided the study in determining factors that influenced the use of ICTs in accessing eresources. It helped to explain how individual and technological characteristics influenced the usage of e-resources among agricultural researchers and extension staff. Figure 1 depicts this model. The first element is technology, which refers to factors based on access to, or the functionality of, a system. Another element is competence, consisting of factors that affect the individual's skills, education, knowledge or experience, and which affect whether they know how to use the technology. These factors vary from user to user. Culture-related values also can influence the use the technologies. Culture includes factors from the external environment such as historic practices, organizational settings, institutional policies, as well as cultural norms and values. The last element, personal values, includes the preferences, beliefs, traditions, and trust that are linked to the individual user's motivation and choice.

In the context of this study, technology means the ICT tools; competence relates to the ability to use the tools for accessing information; cultural-related and personal values influence the usage of the tools either positively or negatively as they affect people's ability to use the tools. Institutions on the other hand should have strategies to encourage the usage of e-resources. 


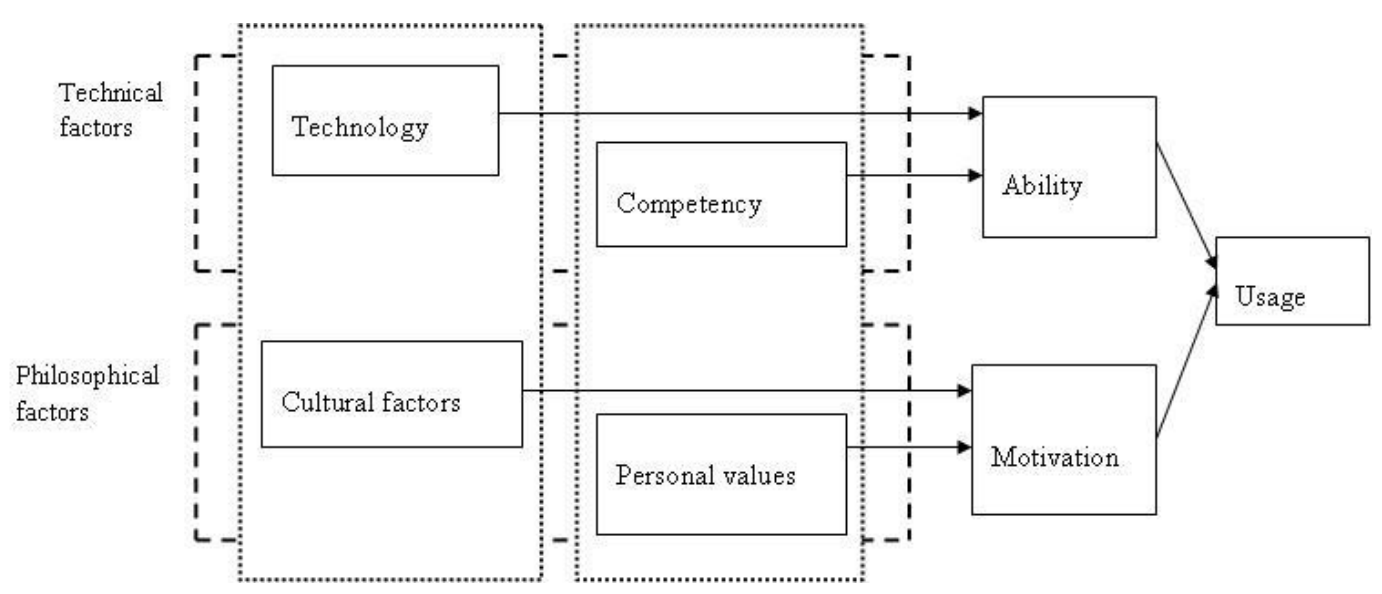

Figure 1: Quadratic Usage Framework (QUF) (Mardis, Hoffman and Marshall, 2008).

\section{Literature review}

This section summarises advantages of e-resources, factors affecting access and use of e-resources and considers how e-resources are used in specific sectors, especially agriculture.

\subsection{Advantages of e-resources}

ICTs facilitate the creation, storage and dissemination of information resources. These technologies enhance access to information when wanted (Ray and Day, 1998). E-resources can be accessed from various ways. Some of the common routes to access e-resources are mentioned by Bhatia and Venkata (2011), including Online Public Access Catalogue (OPAC), search engines and websites. Other e-resources include electronic journals, online databases and CD-ROM databases. People can access information from open access or subscription-based repositories. This study aims to identify factors which influence e-resource choice.

E-resources have several advantages. Multiple users can access the same eresource at the same time. Ray and Day (1998) describe the ease of using eresources and the use of keywords to retrieve information. According to Ray and Day (1998), e-resources open up the possibility of searching multiple files simultaneously; information can be printed or saved for future reference; eresources are frequently updated and they are accessed virtually.

\subsection{Accessing and usage of e-resources}

Access to e-resources is influenced by both individual and technological factors. According to Kabede (2007), the accessibility of e-resources may be affected by the characteristics surrounding the user and information carriers, the characteristics of the contents of the e-resource and the overall information environment. Individual user characteristics such as levels of computer literacy and information literacy, language proficiency and preference to some information formats can also influence access and use of e-resources. E-resource characteristics may influence their accessibility and usage. The other factor influencing the accessibility of e-resources is the characteristic of the information 
carrier. CD or DVD-ROMs and web pages are some common formats of eresources (Sife, Lwoga and Sanga, 2007; Ray and Day, 1998). Accessing eresources in these formats depends on the availability of devices needed for reading, connectivity and one's literacy level.

The accessibility and usage of e-resources can also be influenced by the budget for purchasing devices, such as computers, to access these resources and for subscriptions paid to the publisher for access to a resource (Martin, 2010). When this budget is limited, accessibility and usage of e-resources may be low. Users' awareness about the existence of e-resources is also an important factor in the usage of such resources. Tyagi (2011) describes appropriate strategies to raise awareness in order to increase the usage of e-resources. Posters, e-mail lists, leaflets and brochures can be used to inform users about the available resources.

For users to be able to access and effectively use e-resources, they must also have adequate skills for retrieving information and to evaluate the outputs of the search process. Mardis, Hoffman and Marshall (2008) refer to these skills as the competencies needed to access resources. These competencies include the information literacy skills, including skills to formulate a search, to identify appropriate information sources, to select the right search tools, to employ suitable search strategies and to evaluate the results. According to Bendersky, Metzler and Croft (2012), search formulation involves coming up with appropriate queries useful for finding the information needed by the information seeker. Cats and Lau (2008) point out that search formulation comes after the identification of the information needs. Search formulation helps the information seeker to retrieve information relevant to his or her needs.

After formulating an appropriate search, appropriate information sources should be identified. Information sources are points from where information is accessed. Smith (1997) emphasize that such sources must be credible and trustworthy. Dutta (2009) identified some information sources including:

- non-government organizations (NGOs);

- information centres;

- informal networks (family, friends, and colleagues);

- libraries;

- community radio stations.

The functional view of information sources describes sources as neither good nor bad, but just more or less fruitful or relevant in relation to a given question (Hjørland, 2012). Thus, each information source may be relevant and suitable to specific information needs. For information needs to be met one must identify appropriate information sources and be able to access relevant information. It is thus important to select the right search tools to access information easily. Information must also be evaluated before being used to meet the information needs. According to Devi and Devi (2005), e-resources should be evaluated because they are created at a very high level and that they are meant to be used for a varied audience. Devi and Devi (2005) describe important criteria for evaluating 
an e-resource, to assess its appropriateness for the individual's information need, including:

- the authority behind it;

- currency;

- intended audience;

- $\quad$ ease of use;

- accuracy.

Personal values and educational levels may influence people's ability to evaluate e-resources.

Thus, information literacy can enhance the accessibility and usage of e-resources. However, for effective access to, and usage of, e-resources individual and infrastructural factors must be considered as well. The current study set out to identify these factors, assess their impact and determine how to adjust their influence on accessibility and usage of e-resources.

\subsection{The usage of e-resources in different sectors}

Information sharing is very important in generating new knowledge needed for the socio-economic development. According to Renwick (2005), people use eresources for:

- communication;

- professional development and professional related tasks;

- supporting teaching and administrative tasks;

- personal use;

- research activities;

- recreation.

In the education sector, empirical evidence shows that the uses of e-resources have positive impacts on the teaching-learning process. A study conducted by Bhukuvhani, Chiparausha and Zuvalinyenga (2012) showed that lecturers used eresources for preparing lecture notes which reflect the current state of science and technological development. This positive impact of e-resources to the teachinglearning process is due to the currency of most e-resources compared to print materials. It is also known that a single e-resource can be used by multiple users at a time, which is not the case with print resources. From the user's point of view, e-resources hold many advantages such as time and place convenience, timeliness, ability to search directly on text, ability to link to further reading material and ability to disseminate and share information (Quadri, 2012). The use of eresources in learning institutions usually increases with improved academic performance (Sivathaasan and Velnampy, 2013; Egberongbe, 2011). Academic institutions which have invested much in e-resources infrastructure are more likely to perform better academically. 
Various types of e-resources are used in education, including e-books, e-journals, web based resources, e-databases, data archives, manuscripts, maps, magazines, theses, newspapers, e-mail, research reports and online catalogues (Quadri, 2012; Pandita, 2012; Sharma, 2009; Appleton, 2004). These resources are used as educational materials as they facilitate teaching, learning and research activities.

E-resources have been useful in the agricultural sector in different countries. Thaniskodi (2010a) describes how e-resources are used in India, helping students, lecturers, practitioners and researchers. According to Thanuskodi (2010b), eresources are good sources of information about crop and animal husbandry. These e-resources are disseminated through various channels including the internet, servers and CD / DVD-ROMs (Thanuskodi, 2010b). It is known that for agricultural research to be effective current information is needed. Angello and Wema (2010) describe agricultural researchers' appreciation of the role played by e-resources in their day-to-day activities. A study conducted by Singh and Bebi (2012) in India shows that agriculturalists used e-resources for research work, teaching and for updating themselves with current information.

Generally, e-resources are important for teaching, learning, research and informational purposes. Students, lecturers / tutors, researchers and practitioners are the main users of e-resources. For such resources to be accessed and used ICTs are needed and institutional ICT infrastructure is important in order to ensure optimal usage of such resources.

\section{Methodology}

The study was conducted in five of the seven agricultural zones in Tanzania. Zones included in the study were randomly selected and regions and districts which were close to research institutes were involved in the study. The selected zones included the Eastern, Northern, Lake, Southern Highlands and the Southern zones. Arusha, Mbeya, Morogoro, Mtwara and Mwanza regions were purposively selected because each hosted an agricultural research institute.

A survey method was used, with structured questionnaires being administered to agricultural researchers and extension staff. The questionnaire is shown in the Appendix. Non-probability sampling was used to select respondents to be included in the study. Due to the nature of their work it was difficult to find all agricultural researchers and extension staff at their work stations. It was for this reason that a combination of purposive and convenient non-probability sampling techniques was used to select the respondents included in the sample. Using this approach, people identified in offices during a one week period were selected for the study. The survey was conducted between December 2012 and February 2013. Two non-probability sampling techniques were used due to the advantages of these approaches over other types of non-probability sampling. According to Krishnaswami (2002), purposive and convenient non-probability sampling techniques are less costly and require less time. Krishnaswami (2002) mentions further that convenient sampling techniques can be suitable when dealing with a homogenous population. There were 107 respondents. According to Kothari (2004), a sample size of 30 respondents usually results in a sampling distribution that is very close to the normal distribution. 
Data collected were analysed using the Statistical Package for Social Sciences (SPSS version 18). Regression analysis was performed to show the influence of some factors on the accessibility and usage of e-resources among agricultural researchers and extension staff. This was also used to describe the relationship between variables. Descriptive statistics (frequency distribution and crosstabulation) were used to identify the factors influencing the accessibility and usage of e-resources among members of the study population. Frequency distribution and cross-tabulation tables were used to present the results.

\section{Findings and discussion}

This section presents the findings of the study. It describes the demographic profile of the respondents involved in the study. It examines the types of eresources consulted by agricultural researchers and extension staff, the methods used to access e-resources and the self-described information literacy levels of agricultural researchers and extension staff. Institutional and individual factors which influence the usage of e-resources are also discussed.

\subsection{Demographic profiles of respondents}

The study involved 107 respondents, among them 74 (69.16\%) were agricultural researchers and $33(30.84 \%)$ were extension staff. It was found that majority of the respondents $(73,68.2 \%)$ were male while relatively few $(34,31.8 \%)$ were female. Respondents had different educational levels ranging from Diploma to Doctorate degrees and they were between 25 to 60 years of age (Table 1).

\begin{tabular}{|l|c|c|}
\hline Demographic profile item & Frequency & Percent \\
\hline Sex & 34 & 31.8 \\
\hline Female & 73 & 68.2 \\
\hline Male & 25 & 23.4 \\
\hline Age of respondent (years) & 19 & 17.6 \\
\hline $25-34$ & 46 & 43.0 \\
\hline $35-44$ & 17 & 15.9 \\
\hline $45-54$ & \multicolumn{2}{|l|}{} \\
\hline 55 and above & 29 & 27.1 \\
\hline Education of respondent & 35 & 32.7 \\
\hline Diploma & 35 & 32.7 \\
\hline Bachelor degree & 8 & 7.5 \\
\hline Master degree & 74 & 69.16 \\
\hline PhD & 33 & 30.84 \\
\hline Occupational categories & \\
\hline Agricultural researchers & \multicolumn{2}{|l|}{} \\
\hline Agricultural extension staff &
\end{tabular}

Table 1: Demographic profiles of respondents $(\mathrm{N}=107)$.

\subsection{Usage of e-resources among agricultural researchers and extension staff}

Respondents were asked whether they have ever used e-resources. It was found that the majority (96.3\%) had used e-resources in their work (Table 2). This 
corresponds to findings reported by Nkonoki (2013) indicating that $96 \%$ of the postgraduate students at Sokoine University of Agriculture claimed to use eresources in their research. More than $80 \%$ of scholars globally are moving to use of e-resources instead of print versions (Aqil and Ahmed, 2011).

\begin{tabular}{|l|l|l|}
\hline \multicolumn{3}{|l|}{ Usage of e-resources by level of education of respondents } \\
\hline Level of education & Users & Non-users \\
\hline Diploma & $26(87 \%)$ & $3(13 \%)$ \\
\hline Bachelor degree & $35(100 \%)$ & $0(00 \%)$ \\
\hline Master degree & $35(100 \%)$ & $0(00 \%)$ \\
\hline PhD & $7(87.5 \%)$ & $1(12.5 \%)$ \\
\hline Usage of e-resources by age of the respondent \\
\hline Age group & Users & Non-users \\
\hline $25-34$ & $24(100 \%)$ & $0(00 \%)$ \\
\hline $35-44$ & $30(100 \%)$ & $0(00 \%)$ \\
\hline $45-54$ & $43(95.6 \%)$ & $2(4.4 \%)$ \\
\hline 55 and above & $15(88 \%)$ & $2(12 \%)$ \\
\hline Usage of e-resources by occupation \\
\hline Occupation & Users & Non-users \\
\hline Agricultural researchers & $73(98.6 \%)$ & $1(1.4 \%)$ \\
\hline Extension staff & $30(90.9 \%)$ & $3(9.1 \%)$ \\
\hline
\end{tabular}

Table 2: Respondent usage of e-resources.

The results from the current study are based on respondent self-assessment, meaning that they might not reveal a true picture of the extent to which eresources are actually used. Usage of e-resources in scholarly communication may be assessed through the citation analysis. However, it is important to acknowledge that e-resource usage by the scholarly community continues to increase. Sife and Bernard (2013) conducted a citation analysis of thesis and dissertations at Sokoine University of Agriculture, showing an increase in level of usage of e-resources by postgraduate students taking agricultural programmes. The increasing usage of eresources in Tanzania may also be explained by the limited acquisition of current print resources and may be further motivated by the easy discovery of free contents through search engines such as Google. In Tanzania, Sokoine National Agricultural Library - the largest agricultural library in the country - has stopped subscribing to print journals over the past ten years. According to Omotayo (2010), the decreasing acquisition of print resources among libraries in most developing countries is partly due to dwindling funds for subscriptions. In such a circumstance, it is not surprising for scholars to depend on e-resources and especially those which are freely accessible on the internet, as the only choice to meet their scholarly information needs.

Those who used e-resources had access to both online and offline sources. The findings show that the use of e-resources increased with an increase in level of education of the agricultural researchers and extension staff and decreased with an increase in age of the respondents respectively (Table 2). The decrease of usage of e-resources with an increase of age may be explained by the fact that most of those who graduated before the introduction of computers in some of the Tanzanian universities and some tertiary agricultural training institutes did not 
have opportunities to learn how to use computers. Older agricultural researchers and extension staff who used e-resources probably had computer literacy programmes during their postgraduate programmes. These findings are in line with those of Thanuskodi (2010a) who assessed the use of e-resources among medical professionals. Findings from Thanuskodi's study showed that older medical professionals used e-resources least. Moreover, Thanuskodi (2010a) mentions that older medical professionals lagged behind in realising problems in accessing e-resources.

Table 2 also shows that more agricultural researchers than extension staff used eresources. This may be explained by the nature of their jobs: research activities need more current information. Singh and Bebi (2012) and Jamali, Nicholas and Rowlands (2008) show that in most cases e-resources are more current than print resources. This may explain why more agricultural researchers preferred to use eresources.

\subsection{Sources of e-resources}

Respondents were asked about the e-resources they frequently accessed. Respondents accessed e-resources from different sources. The choice of eresource source depended on availability. The majority of the respondents (84.1\%) had accessed e-resources through search engines particularly Google. Others $(18.7 \%)$ with access to computers had accessed e-resources through CDROMs (Table 3).

\begin{tabular}{|l|l|l|}
\hline E-Resource & Frequency & Percent \\
\hline CD-ROM & 20 & 18.7 \\
\hline AGORA & 8 & 7.5 \\
\hline HINARI & 2 & 1.9 \\
\hline TEEAL & 7 & 6.5 \\
\hline JSTOR & 3 & 2.8 \\
\hline OARE & 1 & .9 \\
\hline Wiley Interscience & 2 & 1.9 \\
\hline Search Engines & 90 & 84.1 \\
\hline
\end{tabular}

\section{Table 3: E-resource sources.}

Surprisingly, few respondents acknowledged having accessed and used popular agricultural databases such as the Access to Global Online Research in Agriculture (AGORA). Funded by Food and Agriculture Organisation of the UN (FAO), AGORA provides free access to a collection of more than 3500 key journals and 3300 books in agriculture and related fields to 116 developing countries, including Tanzania (AGORA, 2014). Only $7.5 \%$ of the respondents claimed to have used e-resources from AGORA. This is may be due to a lack of awareness about the resource. Alternatively, this may be due to the fact that most subscribed e-resources including those from AGORA must be accessed from within an institution. Many people opt to use other freely available resources, which are accessible through search engines such as Google and which have no access limitations. 


\subsection{Access points for e-resources}

Respondents were asked where they accessed e-resources. Various access points were used, with almost $60 \%$ of respondents accessing e-resources from their institutions. It was found that the majority of the agricultural institutes in Tanzania provided ICT related services which enabled respondents to access e-resources. These findings are in line with those of Shetto (2008) which show that most agricultural research institutes in Tanzania have access to basic ICTs. The findings also show that $68.2 \%$ of respondents accessed e-resources through their laptops (Table 4). Mobile phone service providers in Tanzania offer internet data bundles of specified megabytes as part of individual subscription packages. Internet access is possible through mobile phones or on laptops installed with modems. This mode of accessing e-resources may be preferred by some respondents because access is possible from any point within the area covered by the mobile phone network. However, subscribed e-resources would not be accessible through modems if an institutional Internet Protocol (IP) address is required to access full-text. Subscribed e-resources use either usernames and passwords or institutional IP addresses.

\begin{tabular}{|l|l|l|}
\hline Access point & Frequency & Percent \\
\hline Office/institution & 64 & 59.8 \\
\hline Mobile phone & 32 & 29.9 \\
\hline Internet cafe & 58 & 54.2 \\
\hline Laptop modem & 73 & 68.2 \\
\hline
\end{tabular}

Table 4: E-resources access points.

The findings also show that $54.2 \%$ and $29.9 \%$ of the respondents accessed eresources from internet cafes and through their mobile phones respectively. Most agricultural research institutes in Tanzania are located in semi-urban areas with internet cafes. The number of respondents using mobile phones for accessing eresources was lower than those visiting internet cafes. This was not due to limited ownership of mobile phones but rather due to small screen size of the mobile phones which discourage some from using them to access large files.

Generally, there were various options for agricultural researchers and extension staff to access e-resources. The choice of an access point for e-resources depended on individual ownership of devices and institutional ICT infrastructure.

\subsection{Information literacy skills}

Respondents' information literacy (IL) levels were assessed by using four criteria:

- ability to formulate relevant searches;

- identification of appropriate information sources;

- selecting right search tools;

- ability to evaluate the retrieved documents.

Respondents' IL levels were rated using five grades: Excellent, Very Good, Good, Average and Below Average. Excellent meant that the respondent scored more than $80 \%$ in the criteria marking scheme; Very Good indicated that someone 
scored $75 \%-80 \%$, Good meant a score of $60 \%$ to $74 \%$. Average reflected scores between 50\%-59\% and Below Average indicated a score below 50\%.

\begin{tabular}{|c|c|c|c|c|c|}
\hline \multirow[t]{2}{*}{ Criteria } & \multicolumn{5}{|c|}{ Frequency for each competency level } \\
\hline & Excellent & Very good & Good & Average & $\begin{array}{l}\text { Below } \\
\text { average }\end{array}$ \\
\hline $\begin{array}{l}\text { Search } \\
\text { formulation }\end{array}$ & $7(6.5 \%)$ & $\begin{array}{l}21 \\
(19.6 \%)\end{array}$ & $\begin{array}{l}37 \\
(34.6 \%)\end{array}$ & $\begin{array}{l}36 \\
(33.6 \%)\end{array}$ & $6(5.6 \%)$ \\
\hline $\begin{array}{l}\text { Identifying } \\
\text { appropriate } \\
\text { information } \\
\text { sources }\end{array}$ & $10(9.3 \%)$ & $\begin{array}{l}19 \\
(17.6 \%)\end{array}$ & $\begin{array}{l}41 \\
(38.3 \%)\end{array}$ & $\begin{array}{l}31 \\
(29.0 \%)\end{array}$ & $6(5.6 \%)$ \\
\hline $\begin{array}{l}\text { Selecting right } \\
\text { search tools }\end{array}$ & $7(6.5 \%)$ & $\begin{array}{l}17 \\
(15.9 \%)\end{array}$ & $\begin{array}{l}35 \\
(32.7 \%)\end{array}$ & $41(38.3 \%)$ & $7(6.5 \%)$ \\
\hline $\begin{array}{l}\text { Search } \\
\text { evaluation }\end{array}$ & $5(4.7 \%)$ & $13(12.1 \%)$ & $33(30.8 \%)$ & $42(39.3 \%)$ & $14(13.1 \%)$ \\
\hline
\end{tabular}

Table 5: Information literacy levels among respondents.

Regardless of the level of education and occupation, most respondents fell under the Good or Average grades (Table 5). This was based on respondents' selfassessment of their information literacy skills which may not necessarily reflect their true skills. It is possible that respondents rated themselves as having good information literacy skills to disguise ignorance or not realising how much more there is to learn. From experience of information literacy training at Sokoine University of Agriculture, most of trainees seem to realise that they know very little about searching for information from e-resources.

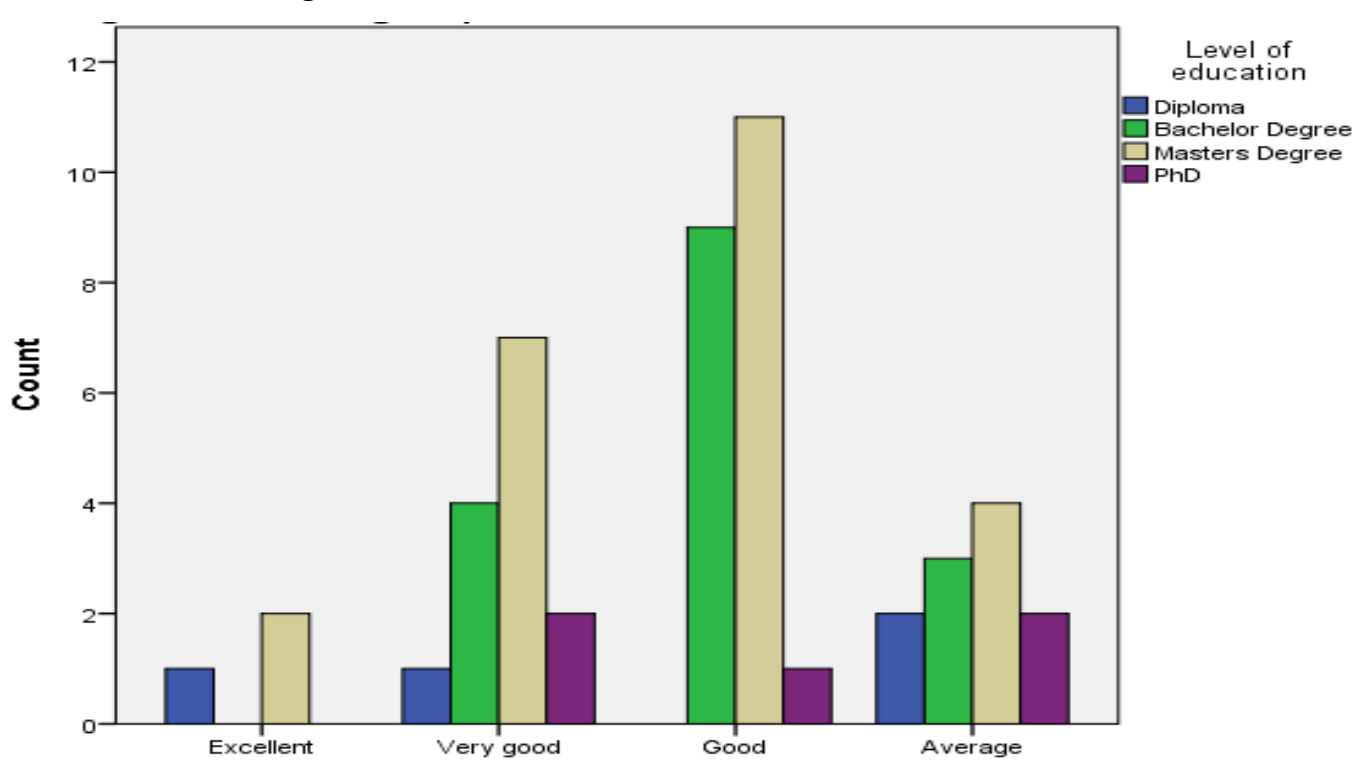

Figure 2: Educational level and search formulation.

The findings suggest that some individual variables, such as level of education can influence the ability to formulate searches (Figure 2). An individual's ability to access e-resources appeared to depend on his or her IL level. The findings showed that only 19 (17.8\%) respondents attended IL courses. Among the information literate were agricultural graduates who had graduated in recent years. 
This may be explained by the fact that Sokoine National Agricultural Library at Sokoine University of Agriculture (SUA) provides information literacy programmes, which graduates from SUA may have undertaken while pursuing their studies.

Similarly, findings indicate that the ability to formulate appropriate searches was higher in some age groups than others (Figure 3). Most of the respondents in the age group 25-54 years were either rated Good, Very Good or Excellent in terms of their ability to formulate good searches. Most of those aged above 55 years were ranked Average in terms of ability to formulate searches. This suggests a negative relationship between the ability to formulate good searches and the age of the respondent. It also meant that the ability to access relevant information from searches decreased as respondent age increased.

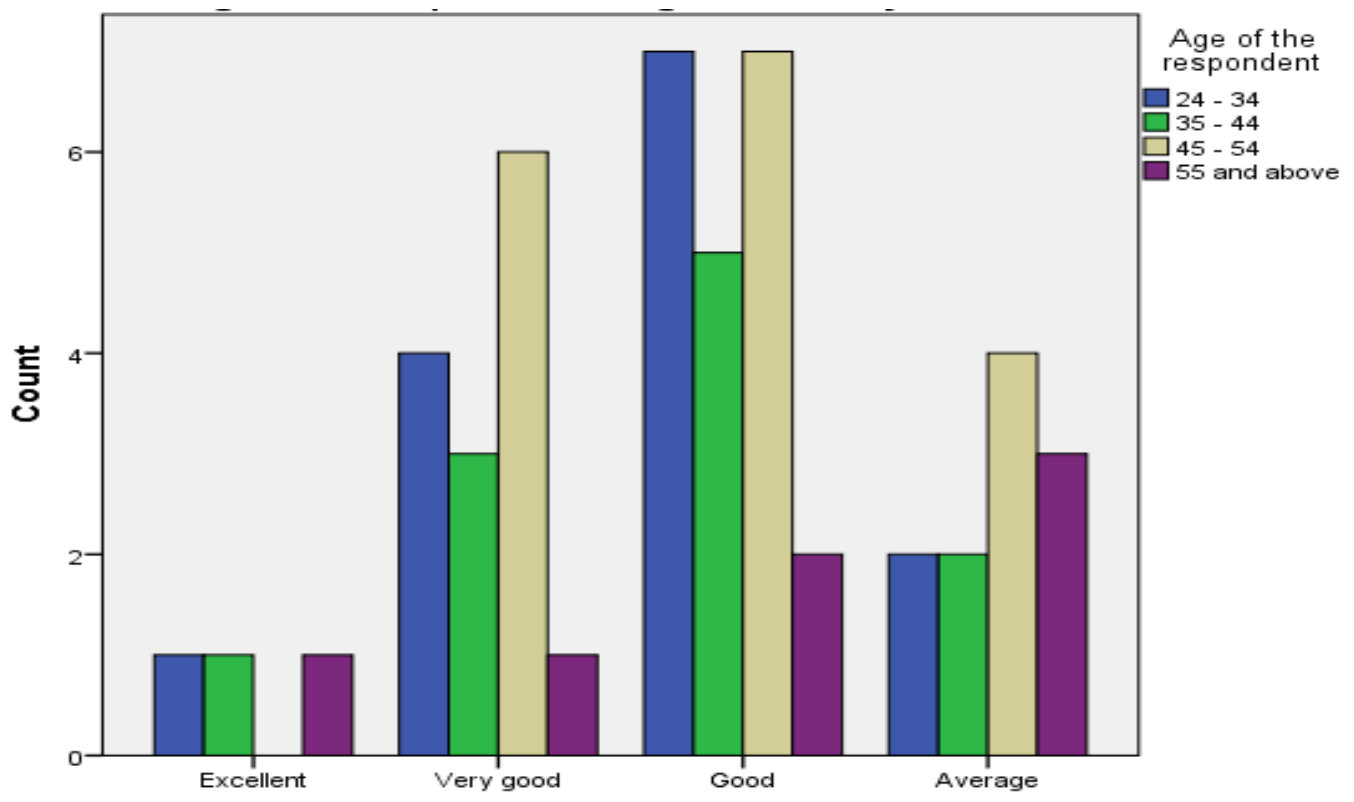

Figure 3: Age and ability to formulate searches.

The other criteria including identification of appropriate information sources, selection of right search tools and conducting appropriate search evaluation were equally influenced by age and level of education. The majority of the agricultural researchers and extension staff were graduates and some had postgraduate qualifications. Given the basic e-resource infrastructure they seemed able to optimize the usage of e-resources in their day to day activities.

\subsection{Factors influencing access and usage of e-resources}

Respondents were asked about common problems limiting access to, and usage of, e-resources. The findings show that respondents encountered several problems shown in Table 6 . The majority of the respondents $(71 \%)$ indicated that slow internet connectivity limited their access to, and use of, e-resources.

$61.67 \%$ of respondents failed to access full texts when downloading e-resources. This may be explained by the fact that most e-resources do provide free access to 
abstracts. To access full text from these e-resources without a subscription, people would have to pay.

\begin{tabular}{|l|l|}
\hline Problem encountered & Response \\
\hline Do not know URLs & $35(32.7 \%)$ \\
\hline Getting too much information & $38(35.5 \%)$ \\
\hline Failing to download & $38(35.5 \%)$ \\
\hline Slow internet connectivity & $76(71 \%)$ \\
\hline Failed to access full text & $66(61.76 \%)$ \\
\hline
\end{tabular}

Table 6: Common problems encountered when accessing e-resources.

$32.7 \%$ of the respondents did not know the URLs to use to access e-resources. $35.5 \%$ thought they got too much information while accessing e-resources. These results may suggest limited information literacy skills among the respondents. Inadequate information literacy skills may particularly limit respondent use of specialised databases such as AGORA. Use of AGORA requires people to memorise URLs, user names and passwords in order to access information. This may be a reason why some failed to access identified e-resources. This further suggests that despite the respondents ranking their information literacy skills as good, some respondents may benefit from more training, in order to improve their use of e-resources.

Individual factors influencing access and use of e-resources included the respondents' occupational category. Findings in Table 1 showed that agricultural researchers used e-resources more frequently than extension staff. It is known that research related activities require very current information resources. Eresources contain very current and up-to-date information which can effectively support research (Wilkins, Swatman and Chan, 2006). Agricultural researchers reported accessing and using e-resources more frequently than agricultural extension staff. It was also found that individual's level of education influenced access and use of e-resources (Table 2). The other factor influencing the accessibility and usage of e-resources was the information literacy level. The findings suggest that most graduates or postgraduates reported higher levels of access and use of e-resources. This may be due to IL courses offered as part of their graduate programmes.

The findings also show that age may influence ability to access and use eresources. Younger agricultural researchers and extension staff used e-resources more than the older ones. Similar findings were observed by Akman and Mishra (2009) who found that age has a remarkable influence on the use of e-resources. This may be explained by the fact that most older agricultural researchers and extension staff pursued graduate and postgraduate programmes before e-resources were introduced in most libraries in Tanzania.

It was further found that individual income had an impact on owning internet access points and their ability to access and use e-resources. Table 4 shows that the majority of the respondents accessed e-resources through the laptops installed with modems. Most agricultural researchers own laptops which they use for accessing internet services and some e-resources. Individuals with enough income may be able to pay for commercial e-resources. For example, Tanzanians can 
access three free journal articles from Africa Journal Online but have to pay 9.00 USD for each additional journal article. For those unwilling to spend their personal income to pay for e-resources, it might be important for them to include budgets for information resources in their research grant applications.

Institutional factors may include concerns about limited investment in ICT infrastructure in Tanzanian agricultural institutes. The findings show that many of respondents accessed e-resources at access points away from their workplace (Table 4). These findings are in line with those of Shetto (2008) who acknowledged that most of the agricultural institutes in Tanzania provided only basic ICT. This has the effect of limiting staff use of e-resources. Most agricultural institutes have internet connections with limited bandwidth, resulting into very slow internet connectivity.

\section{Conclusion and recommendations}

This study investigated access to and usage of e-resources among agricultural researchers and extension staff in Tanzania. Despite the potential of e-resources, the findings show that the usage of popular agricultural e-resources among respondents is still low, possibly due to limited awareness. Limited ICT infrastructure, budgetary constraints and low information literacy levels have also resulted in inadequate access to and low usage of e-resources. Because of the limited subscriptions made by institutes, most of the researchers and extension staff involved in the study relied on freely available and open access e-resources. Access to and usage of e-resources was influenced by individual factors including age, occupational category and the educational level.

Timely access to and usage of e-resources is important in order to increase the efficiency of agricultural research and extension services in Tanzania. The following recommendations should be considered in order to improve access and usage of e-resources in Tanzania:

- Agricultural research institutes and local governments should improve their ICT infrastructure in order to enhance access to e-resources. The fibre optic cable which has been laid through almost every district in the country should be used by responsible authorities to utilise this facility to the maximum. Each research institute and extension office should be connected to the fibre optic cable and should have faster internet connections with adequate bandwidth.

- There is a need for researchers and extension workers to have information literacy training updates so that they can effectively exploit the online information environment. Research and training institutions should evaluate existing knowledge gaps and should then organise appropriate training sessions. These sessions should be used to raise awareness about the eresources available as well as about approaches to searching for information. Information literacy courses in schools, colleges and universities are vital to enhance access to and usage of e-resources.

- Agricultural research institutions should also consider acquiring discovery tools to improve the accessibility of scholarly literature among researchers and extension workers. Online information discovery tools such as LibHub, Primo 
and Summon have been designed to provide a single Google-like search interface for content discovery across multiple platforms (Fawley and Krysak, 2012). With these tools, information searchers are no longer required to know which databases to search, each with different log-ins and passwords as well as different search techniques for each database. Respondents' preference for internet search engines as their main entry point for accessing e-resources suggests that discovery tools may improve usage of useful agricultural databases such as AGORA. To use these tools, librarians and information professionals would need to aggregate relevant information resources together and train users to use such tools effectively.

- In order to enhance knowledge sharing among researchers and extension workers, there is a need to exploit open access for accessing and disseminating agricultural information. By publishing in open access journals, researchers will ensure their research output is readily accessible to extension workers for repackaging before communicating such findings to the farming community. Agricultural research institutes should also develop electronic institutional repositories for their research outputs so that extension staff and other agricultural stakeholders can access local contents immediately, to help solve practical problems faced by local farmers.

- To gain access to more e-resources, agricultural institutes should join the Consortium for University and Research Libraries (COTUL) so that they can enjoy economies of scale associated with collective subscriptions.

\section{References}

AGORA (2014) Access to Global Online Research in Agriculture. URL: http://www.aginternetwork.org/en/ [accessed 24.2.15].

Akman, I. and Mishra, A. (2010) Gender, age and income differences in internet usage among employees in organizations, Computers in Human Behavior, 26(3), 482-490.

Angello, C. and Wema, E. (2010) Availability and usage of ICTs and e-resources by livestock researchers in Tanzania: challenges and ways forward, International Journal of Education and Development using Information and Communication Technology, 6(1), 53-65.

Anunobi, C.V. and Okoye, I.B. (2008) The role of academic libraries in universal access to print and electronic resources in the developing countries, Library Philosophy and Practice [online], 2008(May). URL: http://digitalcommons.unl.edu/libphilprac/189 [accessed 24.2.15].

Appleton, L. (2004) The use of electronic books in midwifery education: the student perspective, Health Information and Libraries Journal, 21(4), 245-252.

Aqil, M. and Ahmad, P. (2011) Use of the internet by research scholars and postgraduate students of the Science Faculty of Aligarh Muslim University, Library Philosophy and Practice [online], 2011(June). URL:

http://unllib.unl.edu/LPP/aqil-ahmad.htm [accessed 24.2.15]. 
Bendersky, M., Metzler, D. and Croft, W.B. (2012) Effective query formulation with multiple information sources. In: Fifth ACM International Conference on Web Search and Data Mining. URL: http://ciir.cs.umass.edu/ bemike/pubs/20121.pdf [accessed 24.2.15].

Bhatia, J.K. and Venkata, R.P. (2011) Information seeking behaviour of students in digital environment: a case study. URL: http://ir.inflibnet.ac.in/bitstrea m/1944/1637/1/45.pdf [accessed 24.2.15].

Bhukuvhani, C., Chiparausha, B. and Zuvalinyenga, D. (2012) Effects of electronic information resources skills training for lecturers on pedagogical practices and research productivity, International Journal of Education and Development Using ICT, 8(1), 16-28.

Carr, M.K.V., Ndamugoba, D.M., Burgess, P.J. and Myinga, G.R. (1992) An overview of tea research in Tanzania - with special reference to the Southern Highlands. In: Proceedings of Conference on Agricultural Research, Training and Technology Transfer in the Southern Highlands of Tanzania: Past Achievements and Future Prospects. October 5-9 1992.

Catts, R. and Lau, J. (2008) Towards information literacy indicators. Paris: UNESCO. URL: https://dspace.stir.ac.uk/bitstream/1893/2119/1/cattsandlau.pdf [accessed 24.2.15].

Chailla A.M. (2001) Implementation of policies and strategies for agricultural information access and use in Tanzania. PhD thesis. University of Natal, South Africa.

Coulson, A. and Diyamett, B. (2012) Improving the contribution of agricultural research to economic growth: policy implications of a scoping study in Tanzania. URL: http://www.theigc.org/wp-content/uploads/2014/08/Coulson-andDiyamett-final-paper.pdf [accessed 24.2.15].

Devi, T.S. and Devi K.S. (2005) Management of e-resources in the modern library information system: an outlook. URL:

URL: http://ir.inflibnet.ac.in/bitstream/1944/1409/1/49.pdf [accessed 24.2.15].

Dutta, R. (2009) Information needs and information-seeking behaviour in developing countries: a review of the research, International Information and Library Review, 2009(41), 44 - 51.

Egberongbe, H.S. (2011) The use and impact of electronic resources at the University of Lagos, Library Philosophy and Practice [online], 2011(December). URL: http://unllib.unl.edu/LPP/egberongbe.htm [accessed 24.2.15].

Fawley, N. and Krysak, N. (2012) Information literacy opportunities within the discovery tool environment, College and Undergraduate Libraries, 19(2-4), 207214.

Heeks, R. (1998) Information technology and public sector corruption. Manchester: Institute for Development Policy and Management.

Hjørland, B. (2012) Methods for evaluating information sources: an annotated catalogue, Journal of Information Science, 38(3), 1-11. 
Jamali, H.R., Nicholas, D. and Rowlands, I. (2008) Scholarly e-books: the views of 16,000 academics results from the JISC national e-book observatory, ASLIB Proceedings: New Information Perspectives, 61(1), 33-47.

Kabede, G. (2007) Factors affecting access to electronic information and their implications. In: Anttiroiko, A. (ed.) Encyclopedia of digital government.

Hershey, PA: Idea Group Reference (IGI) Publishing.

Kapange, B. (2004) ICTs and national agricultural research systems: the case of Tanzania.

URL: http://www.tzonline.org/pdf/ictsandnationalagriculturalresearchsystems.pdf [accessed 24.2.15].

Kothari C.R. (2004) Research methodology: methods and techniques. 2nd ed. New Delhi: New Age International.

Krishnaswami, O.R. (2002) Methodology of research in social sciences. Delhi: Himalaya Publishing House.

Mardis, M.A., Hoffman, E.S. and Marshall, T.E. (2008). A new framework for understanding educational digital library use: re-examining digital divides in U.S. schools, International Journal Digital Library, 9(1), 19-27.

Martin, S. (2010) Open Access and digital libraries: a case study of the text creation partnership. URL: http://repository.upenn.edu/cgi/viewcontent.cgi?articl $\mathrm{e}=1081 \&$ context=library_papers [accessed 24.2.15].

Nkonoki, E. S. (2013) Access to and use of electronic information resources for research by postgraduate students at Sokoine University of Agriculture, Tanzania. M.A. Dissertation. Dar es Salaam: University of Dar es Salaam.

Omotayo, B., O. (2010) Access, use, and attitudes of academics toward electronic journals: a case study of Obafemi Awolowo University, Ile-Ife, Library Philosophy and Practice [online], 2010(March). URL:

http://www.webpages.uidaho.edu/ mbolin/omotayo.htm [accessed 24.2.15].

Pandita, R. (2012) Growing use of electronic sources of information: a user survey of Baba Ghulam Shah Badshah (BGSB) University, Rajouri, Trends in Information Management, 8(1), 43-51.

Quadri, G.O. (2012) Impact of ICT skills on the use of e-resources by information professionals: a review of related literature, Library Philosophy and Practice [online], 2012(June). URL: http://www.webpages.uidaho.edu/ mbolin/quadri.pdf [accessed 24.2.15].

Ray, K. and Day, J. (1998) Student attitudes towards electronic information resources, Information Research [online], 4(2). URL: http://informationr.net/ir/42/paper54.html [accessed 24.2.15]

Renwick, S. (2005) Knowledge and use of electronic information resources by medical sciences faculty at the University of the West Indies, Journal of the American Library Association, 93(1), 21-31. 
Richardson, D. (1996) The internet and rural development: recommendations for strategy and activity - final report. Rome: Sustainable Development Department of the Food and Agriculture Organization of the United Nations.

Sharma, C. (2009) Use and impact of e-resources at Guru Gobind Singh Indraprastha University (India): a case study, Electronic Journal of Academic and Special Librarianship, 10(1), 3-8.

Shetto, M.C. (2008) Assessment of agricultural information needs in African, Caribbean and Pacific (ACP) states Eastern Africa country study: Tanzania. Wageningen: Technical Centre for Agricultural and Rural Cooperation. URL: http://www.researchintouse.com/resources/ext/cta08tz-agriinfoneed-rpt.pdf [accessed 24.2.15]

Sife, A.S. and Bernard, R. (2013) Persistence and decay of web citations used in theses and dissertations available at the Sokoine National Agricultural Library, Tanzania, International Journal of Education and Development using Information and Communication Technology, 9(2), 85-94.

Sife, A., Lwoga, E. and Sanga, C. (2007) New technologies for teaching and learning: challenges for higher learning institutions in developing countries, International Journal of Education and Development using ICT [online], 3(2). URL: http://ijedict.dec.uwi.edu/viewarticle.php?id=246 [accessed 24.2.15].

Singh, K.P. and Bebi. M.S. (2012) Use of e-journals by agricultural scientists: a case study of the ICAR libraries in Delhi, Library Herald, 50(2).

Sivathaasan, N. and Velnampy, T. (2013) Use of electronic information resources and academic performance of university teachers: a case study, European Journal of Business and Management, 5(14), 46-52.

Siyao, P.O. (2012) Barriers in accessing agricultural information in Tanzania with a gender perspective: the case study of small-scale sugar cane growers in Kilombero district, Electronic Journal of Information Systems in Developing Countries [online], 51(6) 1-19. URL: http://www.ejisdc.org/ojs2/index.php/ejisdc/article/view/818/409 [accessed 4.3.15].

Smith, A.G. (1997) Testing the surf: criteria for evaluating internet information resources, Public-Access Computer Systems Review [online], 8(3). URL: http://info.lib.uh.edu/pr/v8/n3/smit8n3.html [accessed 24.2.15]

Thanuskod, S. (2010a) Use of internet and electronic resources for medical science information: a case study, Journal of Communication, 1(1), 37-44.

Thanuskodi, S. (2010b) Use of internet and electronic resources for agricultural science information: a case study, Social Sciences, 5(4), 364-367.

Tyagi, S. (2011) Use and awareness of electronic information sources at IIT Roorkee, India: a case study, Italian Journal of Library and Information Science [online], 2(1). URL: http://leo.cineca.it/index.php/jlis/article/view/4586 [accessed 24.2.15].

United Republic of Tanzania (2005) National strategy for growth and reduction of poverty. Dar es Salaam: Government Printer. 
United Republic of Tanzania (2008) Agricultural sector reforms in Tanzania: perspectives from within. Dar es Salaam: Government Printer.

United Republic of Tanzania (2011) Tanzania agriculture and food security investment plan 2011-12 to 2020-21.

URL: http://www.gafspfund.org/sites/gafspfund.org/files/Documents/TAFSIP_FI NAL FOR PRINTING AND CIRCULATION.pdf [accessed 24.2.15].

Wilkins, L., Swatman, P. and Chan, E. (2006) E-book technology in libraries: an overview, $19^{\text {th }}$ Bled eConference: eValues, Bled, Slovenia, June 5-7, 2006. URL: https://domino.fov.unimb.si/proceedings.nsf/0/6844ce4b1e789dddc12571800031b4eb/\$FILE/21_Wilkin s.pdf [accessed 24.2.15]

\section{Acknowledgement}

This study has been made possible through a grant from Elsevier foundation. Authors highly thank the Foundation for the support given.

\section{Open access and copyright}

Library and Information Research is an open access journal. A freely available copy of this paper may be downloaded from the journal's website: http://www.lirgjournal.org.uk.

Copyright and associated moral rights in works published in Library and Information Research are retained by the author(s) but this paper may be used freely, with proper attribution, in educational and other non-commercial settings. 